\title{
DIFFERENCES IN THE ANTIGENIC PROFILE OF BLOODSTREAM AND CELL CULTURE DERIVED TRYPOMASTIGOTES OF Trypanosoma cruzi.
}

\author{
Ana M. M. da SILVA, Cláudia I. BRODSKYN, Harumi A. TAK EHARA \& I. MOTA
}

\begin{abstract}
SUMMARY
A comparative study of the antigenic profile of bloodstream and cell culture derived trypomastigotes showed many differences in their components. Using mouse anti-T. cruzi antibodies the differences were located mostly in the $120 \mathrm{kDa}$ band, whereas using chagasic patient sera the differences were located in the 85 and 52 $\mathrm{kDa}$ bands. These findings might explain known physiological differences between trypomatigotes obtained from cell culture and from infected blood. A brief report of this work has already been published ${ }^{9}$.
\end{abstract}

KEY WORDS: Trypanosoma cruzi; T. cruzi antigens; Trypomastigotes.

\section{INTRODUCTION}

Trypanosoma cruzi, the protozoan responsible for Chagas' disease has a life cycle involving both mammalian and insect host. In the mammalian host, T. cruzi proliferates as the intracellular amastigote form which differentiates to trypomastigote. Trypomastigotes will enter other cells or reach the bloodstream from where they can be sucked by the insect vector or spread to other tissues. The importance of the mammalian trypomastigotes in the life cycle of T. cruzi justifies the great number of reports available on the antigenic composition of this evolutive form of the parasite. However, due to the difficulties in isolating bloodstream trypomastigotes (BT), most studies have been performed with cell culture derived trypomastigotes (CCDT). Although BT and CCDT are very similar in many aspects, several reports indicate differences in their infectivity to fibroblast cells (L-cells ${ }^{3}$ ) or macrophages ${ }^{7}$ and in their reactivity with anti-T. cruzi antibodies ${ }^{4}$.

These observations prompted us to make a comparative study of $\mathrm{BT}$ and CCDT antigens which are recognized by antibodies present in sera from mice and humans infected with $\mathbf{T}$. cruzi.

\section{MATERIAL AND METHODS}

Parasites: The Y strain of T. cruzi $^{10}$ was used in all experiments. The BT were obtained from the blood of $\mathrm{A} / \mathrm{Sn}$ mice 7 days after infection with $10^{5}$ parasites/animal. The parasites were isolated from the blood components according to the technique described by SILVA et al. ${ }^{8}$ which concisely consists in separating the parasites from blood components by differencial centrifugation followed by hypotonic shock in order

Centro de Pesquisa e Formaçāo em Imunologia da OMS/OPS. Instituto Butantan, Sáo Paulo, Brasil.

Address for correspondence: Dra. Ana Maria Moura da Silva. Centro de Pesquisa e Formaçāo em Imunologia da OMS/OPS Instituto Butantan. Av. Dr. Vital Brasil, 1500. Caixa Postal 65. CEP 05504 Sảo Paulo, SP, Brasil. 
SILVA, A. M. M. da: BRODSKYN. C. I.: TAKEHARA. H. A. \& MOTA. I - Differences in the antigenic profile of bloodstream and cell cultures derived trypomastigotes of Trypanosoma cruzi. Rev. Inst. Med. trop. S. Paulo, $31(3)$ : $146 \cdot 150,1989$

to eliminate contaminant red cells and passage through a CM cellulose column for removal of leucocytes and platelets.

CCDT were obtained from LLC-MK2 cells infected 7 days previously and maintained in $\mathrm{Ea}$ gle's medium containing $10 \%$ FSC (fetal calf se rum) at $37^{\circ}$ under $5 \% \mathrm{CO}_{2}$. After isolation $\mathrm{BT}$ and CCDT were washed 3 times with PBSG (phosphate buffered saline plus $1 \%$ glucose) containing PMSF (phenylmethylsulfonyl fluoride), TLCK (tosyl-lysine chloro-methyl ketone) and EDTA (ethylenediaminetetraacetic acid) at the concentration of $1 \mathrm{mM}$. The parasite containing pellet was stored at $20^{\circ}$ until use.

Immune sera: groups of $20 \mathrm{~A} / \mathrm{Sn}$ mice, 5 weeks old, were injected intraperitoneally (i.p.) with 15 blood forms of the parasite. Mice were treated with nifurtimox in drinking water 10.5 $\mathrm{mg} / \mathrm{ml}$ ) until day 21 post infection (p.i.), in order to avoid mortality due to acute infection. The immune sera were obtained by bleeding the animals by the axial plexus under ether anaesthesia on day 15 and 28 p.i. The sera collected were pooled separately and kept frozen $\left(-20^{\circ}\right)$ until use; to obtain hyperimmune sera the animals received 3 additional doses of $100 \mathrm{BT}$ on day 49,56 and 63 p.i. and were bled on day 70 p.i. Sera were also collected from uninfected mice.

Sera from Chagas' disease patients: sera we re obtained from patients with the chronic phase of Chagas' disease with positive specific serological tests (complement fixation, haemagglutination and immunofluorescence test) and stored at $-20^{\circ}$.

Detection of IgG anti-T. cruzi antibodies: titrations of IgG anti-T. cruzi antibodies in sera were performed by ELISA using as antigen lysa tes of epimastigotes grown in LIT (Liver Infusion Tryptose) medium ${ }^{2}$. Anti-mouse IgG and antihuman IgG labeled with peroxidase were used as conjugates and OPD (ortophenilenediamine) $/ \mathrm{H}_{2} \mathrm{O}_{2}$ as the enzyme substrate.

SDS.PAGE and Western Blotting: CCDT and BT pellets were solubilized in Tris buffer pH 6.8 containing $2.5 \%$ SDS (sodium dodecyl sulfate), $2.5 \%$ 2-mercaptoethanol, $10 \%$ glicerol, $0.001 \%$ bromophenolblue, $1 \mathrm{mM}$ PMSF, $1 \mathrm{mM}$
TLCK and $1 \mathrm{mM}$ EDTA, at concentrations of $4 \times 10^{8}$ cells $/ \mathrm{ml}$. The suspensions were boiled for $3 \mathrm{~min}$ and $0.5 \mathrm{ml}$ of the mixtures were applied to a $10 \mathrm{~cm}$ polyacrylamide gel $10 \%$ or $7.5 \%$. The electrophoresis was performed as described by LAEMMLI ${ }^{5}$ and the separated antigens trans ferred to nitrocellulose membranes according to TOWBIN et al ${ }^{11}$. In order to analyse $\mathrm{BT}$ and CCDT antigens, the nitrocellulose membranes were treated with sera of different groups of mice or sera from chagasic patients, followed by addi. tion of anti-mouse IgG or anti-human IgG labeled with peroxidase and $\mathrm{H}_{2} \mathrm{O}_{2}$ plus 4-chloro-1 naphtol as the enzyme substrate.

\section{RESULTS}

Pattern of antigens recognized by antibodies obtained during the course of murine infection: in order to cumpare the antigenic profile of BT and CCDT, we analysed by Western blotting the parasite antigens recognized by sera of infected mice collected on day 15 p.i., when parasitaemia reachs its peak, day 28 p.i., when it reachs its lowest level and day 70 p.i., in the chronic phase of the infection when the animals are fully resistant to a lethal dose of the parasite The ELISA titres of the anti-T. cruzi antibodies in these sera were 20,640 and 1280 respectively.

In spite of the very low antibody titre detec ted in sera from day 15 p.i., these antibodies already detected faint bands in the blots of proteins having about 100 to $150 \mathrm{kDa}$, present on both BT and CCDT (Figure 1). Hyperimmune sera and sera from the $28^{\text {th }}$ day p.i., detected al. most the same antigens. These sera showed an expected homology between the BT and CCDT antigenic profiles, major homology antigens being located on the 72 and $76 \mathrm{kDa}$ regions. In addition, these 2 sera detected also differences between $\mathrm{BT}$ and CCDT antigens. As shown in Figure 1, the $120 \mathrm{kDa}$ band was more intensely stained in CCDT than in BT, and the $40 \mathrm{kDa}$ band was present only in $\mathrm{BT}$.

BT and CCDT antigens recognized by antibodies present in sera of chronic chagasic patients: the antigenic profiles of $\mathrm{BT}$ and CCDT revealed by 9 human chagasic sera were also studied. 
SILYA A. M. M. da: BRODSKYN, C. I. TAKEHARA. H. A \& MOTA. I - Differences in the antigenic profile of hlowdstream and cell cultures derived trypomastigotes of Trypanosoma cruzi. Rev. Inst. Med. trop. S. Paulo, 3) $3: 146150,1989$

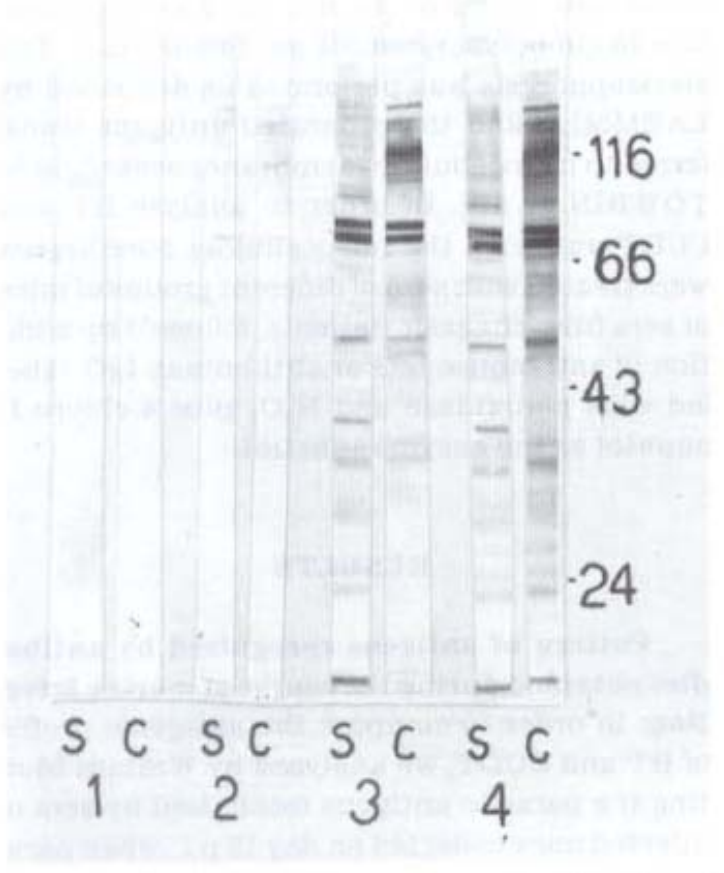

Fig. 1 - Antigens of bloodstream (S) and cell culture derived C) trypomastigote forms of $x$. cruzi traceionated by SDS PAGE $(10 \%)$ and recognized by normal mouse serum (1), serum of mice on the $15^{\text {th }}$ day p.i. 12 ), serum of mice on the $28^{\text {th }}$ day p.1. ( 3 ) and hyperimmune serum (4) by Western blotting. Mr values are shown on the right.

It is in teresting to observe that the antigenic profile revealed by human sera (Figure 2 ) is diffe rent of that obtained by mouse sera (Figure 1 ). The recognition pattern of trypomastigote anti gens detected by these different human sera was also variable. Some of chagasic patient sera (se rum number 2, 3, 4, 5 and 6 ) detected only a few differences between BT and CCDT antigens related to band mobility and intensity of stai ning. whereas others (serum number 7,8 and 9 ) detected more differences in distinct regions of the blots. These differences consisted either in the presence of bands in only one of the anti. gens or in bands more intensively stained in one antigen than in the other.

The most interesting observation in this stu dy was that with all the 9 human sera analysed the bands located in the 85 and $52 \mathrm{kDa}$ regions were more intensively stained in CCDT antigens, whereas the region of the high molecular weight antigens showed a larger number of more strongly stained bands in BT antigens (Figure 2 ).

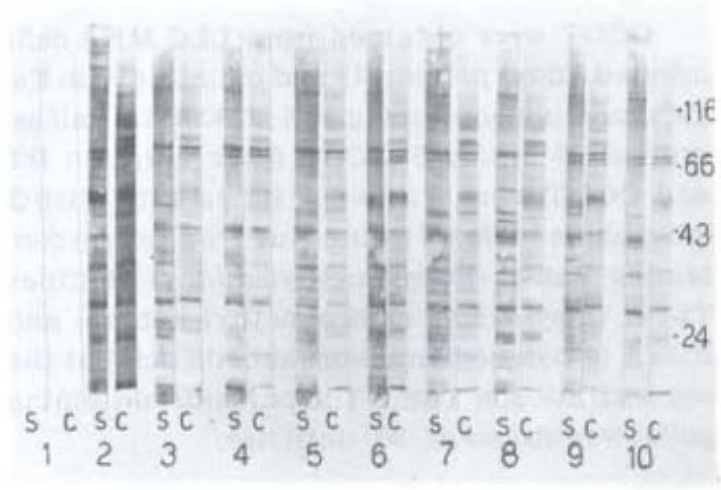

Fig. 2 - Antigens of bloodstream (S) and cell culture derived (C) trypomastigote forms of $\mathbf{T}$. eruzi fraccionated by SDS PAGE $(10 \%)$ and recognized by normal human serum (1), or chro nic patients sera $(2-10)$ by Western blotting. Mr values are shown on the right.

\section{DISCUSSION}

Comparison between $\mathrm{BT}$ and CCDT antigens recognized by antibodies present on different sera showed differences among some of their components detected either singly by some of the sera or by all of them. These differences are probably not due to antigen loss during the isola tion of the BT since the CM cellulose method used for their isolation does not seem to alter the antigenic profile of the parasites ${ }^{8}$.

The antigenic pattern of both BT and CCDT was very much dependent on the serum used to detect the antigens. Thus, antigens revealed by mouse sera always showed a simpler pattern than those detected by chagasic patient se ra. Even within the small number of human sera tested - 9 - we detected considerable differen ces in the antigens recognized by their antibo. dies. On this regard, it must be pointed out that in contrast with infection in humans, experimen. tal mice infection is usually performed by inoculation of a fixed number of one specific strain of the parasite in a specific strain of inbred mice. This probably explains why several pools of hy perimmunized mice sera detected almost the same trypomastigote antigens. Conversely, natural infection of humans differs according to several unknown variables such as the dose of the 
SILVA, A. M. M. da; BRODSKYN, C. I.; TAKEHARA. II. A. \& MOTA, I - Differences in the antigenic profile of bloodstream and cell cultures derived trypomastigotes of 'Trypanosoma cruzi. Rev. Inst. Med. trop. S. Paulo, 31(3): $146-150,1989$

inoculum, strain of the infectant parasite and the genetic background of each infected host. Thus, the variation in the antigenic composition of the parasite plus the uniqueness of the immu ne response result in activation of different clo nes of lymphocytes and in the production of anti bodies with different specificities. On the other hand. differences in the reactivity of each antise rum with BT or CCDT antigens may also be due to either qualitative differences in the epitopes of their antigens or to quantitative differences in the expression of the whole antigen. In order to define this matter, experiments must be done with the antigens fractionated by $2 \mathrm{D}$-electropho resis and/or monoclonal antibudies against each of the peptides where the differences are detec ted.

The observation that the $85 \mathrm{kDa}$ band is mo re intensely stained in CCDT than in $\mathrm{BT}$ may be related to the function that this antigen may play in the infectivity of trypomastigotes to cells ${ }^{1}$. If that is true, it might offer an explanation for previous studies showing that CCDT are mo re infective to cells "in vitro" than BT.3.

LANAR \& MANNING $^{6}$ have also made a comparative study of CCDT and BT antigens using the Western blotting technique but they did not detect any difference between these anti gens. However, the sera samples they used detec ted only the major antigens of the parasite whe reas in our experiments, differences between $\mathrm{B}^{\prime} \mathrm{T}$ and $\mathrm{CCDT}$ were not related to the major antigens. This fact probably explains the discrepan ce between both results.

Conciuding, in spite of the great homology observed between the antigenic profile of $\mathrm{BT}$ and CCDT, there are also important differences among some of their antigenic components that might offer an explanation to some discrepant results found in the literature where $\mathrm{BT}$ and CCDT were used assuming that they have the same antigenic composition.

\section{RESUMO}

Diferenças no perfil antigênico de tripomastigotas sangüicolas e de cultura celular do Trypa nosoma cruzi

O estudo comparativo do perfil antigênico de tripomastigotas sangüicolas e tripomatigotas obtidos por cultura celular do Trypanosoma cruzi revelou que estas formas apresentam diferen ças em alguns de seus componentes Utilizan do-se anticorpos provenientes da infecção muri na, as diferenças foram detectadas na regiāo de $120 \mathrm{kDa}$ enquanto soros de pacien tes chagásicos detectaram diferencas nas regiòes de 85 e $52 \mathrm{kDa}$. Estas observaçōes podem oferecer uma explica çào a diferenças fisiológicas que ocorrem entré os tripomastigotas sanguicolas e os obtidos de cultura celular.

\section{ACKNOWLEDGMENTS}

This work was supported by Conselho $\mathrm{Na}$ cional de Pesquisas, Brasil (Process 40.0695:85 We thank Mr. Carlos Jared for technical assis tance and Dr. Rodolfo Pereira Mendes for kindly providing the sera of Chagas' disease patients.

REFERENCES

1. ALVES, M.J. M. ABUIM.G KUMAIIMA. V. Y \& COLLI, W. - Partial inhibition of trypomastigote entry into cultu red mammalan cells by monorlonal antibodies against. a surface glycoprotein of Trypanosoma crua. Molec. Biochem. Parasit., 21:7582,1986

2. HOSHINO SHIMIZU, S., CAMARGO, M. E. SHIMIZU, T. \& NAGASSE, T. K. - A study on the reproductibility of a stabie, lyophilised reagent for the Chagas disease haemagglutination test proposials for quality control ana lysis. Rev. Inst. Med. trop. S. Paulo, 24:63:68,1982

3. KANBARA, H. \& NAKABAYASHI. T - Comparative studies on trypomastigotes of Trypanosoma cruai from infected mouse blood and infected fibroblast cell (L coll) culture Biken J., 26: $5762,1983$.

4. KANBARA, H. \& NAKABAYASHI. T -- Comparative studie's on surface antigenicity of Trypanosoma cruzi try pomastigotes from infected mouse blood and infected $\mathrm{L}$ cell. Biken J., 28: 7177,1985

5. LAEMMLI, U, K - Cleavage of structural proteins during the assembly of the head of bacteriophage T4. Nature. 227: 680685,1970

6. LANAR, D E. \& MANNING, J E. Major surface proteins and antigens on the different "in vivo" and "in vitro" forms of Trypanosoma cruzi. Mol. Biochem. Parasit.. 11: 119131.1984

7. MEIRELLES. M. N. L.; CHIARI. E. \& SOUZA, W. -... Inte raction of bloodstream tissue culture derived and axenic culture derived trypomastigotes of Trypanosoma cruri with macrophages Acta trop. (Basel), 39: $195203,1982$. 
SILVA, A. M. M. da; BRODSKYN, C. I.; TAKEHARA, H. A. \& MOTA, I - Differences in the antigenic profile of bloodstream and cell cultures derived trypomastigotes of Trypanosoma cruzi. Rev. Inst. Med. trop. S. Paulo, 31(3): 146-150, 1989 .

8. SILVA, A. M. M.: COSTA. H. H.; TAKEHARA, H. A. \& MOTA, I. - Trypanosoma cruzi: advantages of isolating bloodstream trypomastigotes by the carboxymethyl cel. lulose method. Trans. roy. Soc. trop. Med. Hyg., 82: $715-718,1988$

9. SILVA, A. M. M.; BRODSKYN, C. I.: TAKEHARA, H A. \& MOTA, I. - Comparison between the antigenic com position of bloodstream and cell culture-derived trypomastigotes of Trypanosoma cruzi. Braz. J. med. biol. Res., 21: $991-993,1988$
10. SILVA. L. H. P. \& NUSSENZWEIG, V. - Sobre uma cepa de Trypanosoma cruzi altamente virulenta para camundongo branco. Folia clin. biol., 20: 191-207, 1953.

11. TOWBIN, H.: STAEHELIN, T \& GORDON, J. - Electro phoretic transfer of proteins from polyacrylamide gels to nitrocellulose sheets: procedure and some applications. Proc. nat. Acad. Sci. (Wash.), 76: 4350-4354, 1979

Recebido para publicaçăo em 2/11/1988. 